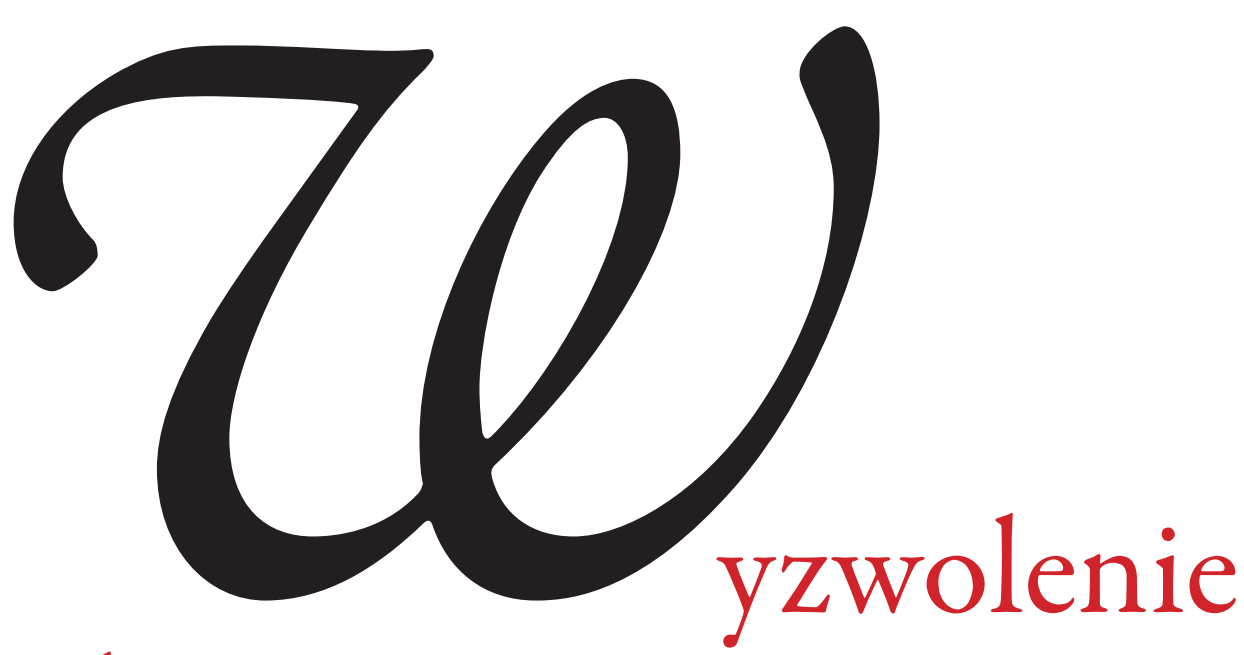

obozu

koncentracyjnego

Bergen-Belsen (1945)

\author{
Relacje świadków
}

Sztuka Edycji 2/2021

ISSN 2084-7963 (print)

ISSN 2391-7903 (online) s. 41-49 
W artykule chciałbym odnieść się do tematu schyłku wojny w obozie koncentracyjnym Bergen-Belsen przedstawionym z perspektywy więźniów, którzy przetrwali w nim do ostatniego lub niemal ostatniego momentu - zrobię to na przykładzie wybranych tekstów literackich. Przywołam również relacje innych świadków, m.in. reporterów i personelu medycznego, którzy weszli do obozu w połowie kwietnia 1945 roku.

\section{Historia Bergen-Belsen}

Początki obozu koncentracyjnego Bergen-Belsen w Dolnej Saksonii sięgają 1935 roku, choć wówczas przeznaczenie tego miejsca było jeszcze zupełnie inne. Teren pełnił początkowo funkcję poligonu wojskowego. Następnie w wybudowanych tam barakach przechowywano broń zdobytą w Czechosłowacji zimą 1938/1939. Pierwsi więźniowie pojawili się w Bergen-Belsen w 1940 roku po zajęciu przez Niemców Belgii i Francji. Następne transporty, z jeńcami radzieckimi, nadeszły w 1941 roku. W obozie panowały już wówczas skrajnie trudne warunki i wysoka śmiertelność mimo że osadzano tam nowe osoby, liczba więźniów utrzymywała się na podobnym poziomie ok. 14 000. Ci, którzy przeżyli, zostali latem 1942 roku skierowani do pracy $^{2}$. Po kilku miesiącach charakter miejsca uległ zmianie - obóz został przeznaczony do specjalnych, politycznych celów:

Wiosną 1943 r. na mocy zarządzenia Reichfuhrera SS Heinricha Himmlera utworzono w Bergen-Belsen „obóz pobytowy” (Aufenthaltslager). Obóz ten różnił się znacznie od pozostałych obozów koncentracyjnych w Niemczech. Był on początkowo przeznaczony tylko dla Żydów, przy czym nie chodziło o ich „likwidację” w ramach całkowitego rozwiązania kwestii żydowskiej w Niemczech. Obóz ten powstał ze względów taktycznych, podyktowanych celami polityki zagranicznej III Rzeszy.

W pierwszym rzędzie chodziło o zgromadzenie tu wszystkich Żydów, posiadających obce obywatelstwa państw zaprzyjaźnionych z Rzeszą hitlerowską, lub państw neutralnych, które mogłyby upomnieć się o swych żydowskich obywateli.

Drugim powodem była chęć wymiany Żydów, posiadających obce obywatelstwa państw znajdujących się w stanie wojny z Niemcami na obywateli niemieckich internowanych w tych krajach. Chodziło naturalnie o wymianę z państwami zachodnimi. Nie dotyczyło to obywateli radzieckich pochodzenia żydowskiego ${ }^{3}$.

Jeszcze w połowie 1943 roku do Bergen-Belsen przewieziono od 2300 do 2500 osób z Polski - posiadaczy dokumentów państw południowoamerykańskich lub tzw. certyfikatów palestyńskich, którzy stawili się w Warszawie w Hotelu Polskim, zgłaszając akces do ówczesnego „obozu pobytowego”. Na początku 1944 roku przeznaczenie Bergen-Belsen uległo jednak zmianie. W marcu trafili tam chorzy więźniowie z innych obozów - mieli odzyskać siły, a następnie powrócić do miejsc pracy przymusowej. $Z$ ok. 1000 osób z tej grupy wyzwolenia doczekało zaledwie 57 . Zdecydowanie niższa śmiertelność panowała wśród osób, które przybyły do Bergen-Belsen jeszcze w 1943 roku.

W połowie 1944 roku do obozu trafiło wiele kobiet biorących udział w powstaniu warszawskim. We wrześniu i w październiku przybyli tam żołnierze Armii Krajowej, zarówno kobiety, jak i mężczyźni; następnie - kobiety i dziewczęta, które również walczyły w powstaniu, jednak pojmane najpierw wysłano do Oświęcimia. Pod koniec 1944 roku Bergen-Belsen przekształcono w obóz koncentracyjny, a jego komendantem został Joseph Kramer, były zwierzchnik Auschwitz-Birkenau. Na przełomie 1944 i 1945 roku do Bergen-Belsen przywieziono 40-50 000 więźniów z innych obozów. Baraki były przepełnione, wiele osób chorowało, brakowało urządzeń sanitarnych, stale zmniejszano racje żywnościowe. Jeszcze na początku kwietnia do obozu przybywały nowe transporty ${ }^{5}$. Równocześnie, między 6 a 11 kwietnia, z Bergen-Belsen trzema pociagami wywieziono ok. 8000 więźniów - jeden z nich dotarł do celu (Terezin; niem. Theresienstadt $)^{6}$, dwa następne transporty przejęli i oswobodzili Amerykanie (okolice Magdeburga) oraz Rosjanie (okolice Tröbitz) ${ }^{7}$. Obóz Bergen-Belsen został wyzwolony przez Anglików 15 kwietnia 1945 roku.

\section{Losy więźniarek - na przykładzie dwóch życiorysów}

W Yad Vashem znajduje się kilka teczek dotyczących Rivki Levi zawierających m.in. wiersze oraz relację jej autorstwa z pierwszego dnia po wyzwoleniu Bergen-Belsen. Co ciekawe, teczki opisano imieniem i nazwiskiem oraz podano informacje w kilku wariantach: Rivka Levi-Schwarzbart (O.76.2, t. 83), Regina Rivka (Schwarzbart) Levy (O.76.2, t. 305; ur. 1920 w Zduńskiej Woli), Rivka Regina 
Levy (O.76.2, t. 309; ur. 1921, „prawdopodobnie w Łodzi”), Rivka (Shwartzbart) Levi (O.3, t. 7440, V.T./446; ur. 1920 w Zduńskiej Woli). Analiza materiałów archiwalnych wykazała, że w każdym wypadku mowa o tej samej osobie.

Rivka Levi była więźniarką Bergen-Belsen w pierwszej połowie 1945 roku aż do jego wyzwolenia. Wcześniej przebywała w takich miejscach, jak getto w Zduńskiej Woli i Łodzi, następnie przez prawie tydzień była w Auschwitz-Birkenau, później w Uphusen i Obernheide („podobozy” obozu w Bremie). Wśród pozostawionych przez tę autorkę materiałów znajduje się notes z wierszami, jak również fragment wspomnień (spisany w dwóch wariantach). Po wyzwoleniu Bergen-Belsen Levi, podobnie jak wiele byłych więźniarek, trafiła do Szwecji, gdzie przechodziła rekonwalescencję. W Skandynawii poznała przyszłego męża, Shlomo Levy’ego; oboje postanowili wyjechać do Palestyny. Wypłynęli statkiem w styczniu 1947 roku, jednak w lutym zostali zatrzymani na Cyprze przez Brytyjczyków - zostali skierowani do obozu przeznaczonego dla nielegalnych żydowskich imigrantów.

Do Izraela dotarli w $1948 \mathrm{roku}^{8}$.

Druga autorka, Nina Gitler, prawdopodobnie już od 1940 roku przebywała w getcie warszawskim. Udało jej się stamtąd wydostać wraz z rodziną pod koniec kwietnia 1943 roku, gdy trwało powstanie. Następnie przez Hotel Polski trafiła do Bergen-Belsen. Przebywała tam prawdopodobnie do 9 kwietnia 1945 roku, nie doczekawszy wyzwolenia. Wraz z matką i ojcem została skierowana do obozu w Tröbitz. Niemcy liczyli bowiem na to, że przynajmniej część więźniów uda się w przyszłości wymienić na jeńców wojennych. Pociąg zatrzymał się jednak 22 lub 23 kwietnia ok. 3,5 km od miejscowości docelowej. Więźniowie zostali uwolnieni przez Armię Czerwoną9 . Informacje na temat Gitler można odnaleźć w dokumentach przechowywanych w Yad Vashem w jednostce o sygnaturze: O.76, t. 201, a także w Żydowskim Instytucie Historycznym w kolekcji „Utwory literackie”: sygn. 226, t. 95 oraz t. 502. Tę ostatnią oznaczono jako NN, jednak bez wątpienia, czego dowodzi przeprowadzona analiza, zawiera utwory Gitler. W teczkach znajdują się przede wszystkim niepublikowane teksty literackie tej autorki: wiersze, utwory prozatorskie, opowiadania i bajki, fragment wspomnień. Gitler zmarła tuż po wojnie w tragicznych okolicznościach (została potrącona przez samochód) 19 listopada 1945 roku w wieku zaledwie dziewiętnastu lat.

W pierwszych miesiącach 1945 roku obóz był przeludniony, znajdowało się w nim trzykrotnie więcej więźniów, niż teoretycznie mogło. $\mathrm{Z}$ powodu tyfusu, gruźlicy i czerwonki zmarło wówczas 20-30 000 osób (dokładna liczba nie jest znana). Jeden z ostatnich transportów do Bergen-Belsen przybył jeszcze 5 kwietnia ${ }^{10}$. Równocześnie więźniów wywożono m.in. do Tröbitz, do którego miała trafić Nina Gitler. Jak już jednak wspomniano, pociąg nie dojechał do celu. Dopiero wówczas, 22 lub 23 kwietnia, kobieta odzyskała wolność. Część byłych więźniów udała się do pobliskiej miejscowości (niestety jej nazwy nie podano):

Zebrałyśmy na mieście trochę pościeli, rzeczy. Domy były puste, jakby miasteczko wymarło. Mieszkańcy siedzieli ukryci po piwnicach, niektórzy, bardziej znani „nazi” ukrywali się w innych miastach. Miasteczko było nasze - grupy byłych obozowiczów. Nagle wjechał rosyjski kapitan i spytał, czemu bez rozkazu wyszliśmy z pociągu. Okazało się, że pierwszy bojec, mówiąc nam, żebyśmy zajęli miasteczko, kierował się tylko czysto ludzkim uczuciem. Ale już było za późno. Epidemia tyfusu zawleczony tygodni zdziesiątkować ludność, zarówno spośród nas, jak i mieszkańców, którzy powoli powyłazili ze swych nor i zajęli najgorsze pomieszczenia w miasteczku. Rodzice moi przewidzieli tę epidemię km dalej, gdzie nie było obozowców ani Rosjan ${ }^{11}$.

Gitler wraz z rodzicami znalazła się we wsi Wildgrube, gdzie czekała na rozwój sytuacji, przebywając w opuszczonym domu. W wielu okolicznych miejscowościach rozlokowali się inni dawni więźniowie obozów, panowała epidemia tyfusu. Przez Wildgrube - jak się wkrótce okazało - często przejeżdżali Rosjanie, którzy chętnie odwiedzali Gitlerów (słowa nieczytelne oznaczono [-]):

Weszło więc 20 bojców, zajęli wszystkie krzesła i łóżka, jeden wyjął ręczną harmonijkę i zaczął grać. Sytuacja była dla mnie niebezpieczniejsza, niż sobie z tego zdawałam sprawę. Odbywało się wtedy powszechne gwałcenie kobiet przez pijanych i niepijanych żołnierzy. Jedni mścili się w ten sposób na Niemcach za ich wyczyny z okresu inwazji na Rosję, inni uważali to za rodzaj sportu. Wszystkie Niemki zostały wielokrotnie zgwałcone przez całe kompanie - zarażone syfilisem lub innymi chorobami. Moi rodzice doceniali niebezpieczeństwo - pijany nie odróżnia już Niemki od „sojuszniczki”. Kilkakrotnie pró- 
bowałam wyjść z pokoju, ale bojcy głośno protestowali. Wreszcie doszedł jeden do mnie - siedziałam między rodzicami - i spytał zupełnie serio, czy chcę za niego wyjść za mąż. Widzę, że ty politycznie uświadomiona i nie rozpuszczona jak dzisiejsze dziewczęta - mówił - ja jestem mechanikiem, dużo zarabiam. Kupię ci buty, suknię, palto, maszynę do szycia, mam domek, będziesz chodować [sic!] kury - błagam cię, powiedz, że chcesz być moją żoną. W pierwszej chwili myślałam, że to kpiny, ale dobrze mu patrzyło z oczu i naprawdę sądząc, że wojna się kończy, chciał sprowadzić sobie na daleki Sybir żonę. Obiecał, że weźmie i moich rodziców i urządzi ich, nic nie chciał - tylko słowo, że będę na niego czekać w małej niemieckiej wiosce aż przyjedzie i pobierze się ze mną. Od razu wszyscy inni nabrali dla mnie uszanowania i wypili za zdrowie narzeczonych. Rodzice moi krztusili się ze śmiechu. Nazajutrz kompania ruszyła dalej. Potem przyzwyczaiłam się już, że co dzień 8-10 żołnierzy, [-] poruczników przychodziło do matki prosić o moją rękę, tłumacząc, że chcą od razu po wojnie ustabilizować byt.

Jestem pewna, że wielu wróciło szukać mnie do wsi Wildgrube ${ }^{12}$.

Przytoczone wyżej wspomnienia oddają atmosferę drugiej połowy kwietnia 1945 roku, tymczasowości, obrazując losy wielu byłych więźniów, którzy nie doczekawszy wyzwolenia w obozie, znaleźli się na wolności w innych okolicznościach. W relacji Gitler można nawet dostrzec akcenty humorystyczne.

Po kilku tygodniach pobytu w Niemczech Nina, prawdopodobnie na początku czerwca, wróciła do Polski. Następnie bardzo szybko zdecydowała o tym, by wyjechać z kraju, a później w listach namawiała do tego także swoich rodziców. Przez Czechy dotarła do francuskiej strefy okupacyjnej w Niemczech, gdzie pozyskała - prawdopodobnie fałszywe - dokumenty chilijskie, a potem zamieszkała w Jordanbad i otrzymała pracę jako sekretarka dyrektora UNRRA w Biberach. Kilka miesięcy później zginęła w wypadku.

\section{Ostatnie dni Bergen-Belsen}

\section{w wierszach byłych więźniów}

W utworach literackich, które powstały w niemieckim obozie w pierwszych miesiącach 1945 roku, pojawia się motyw nadchodzącej wolności. Posiłkowano się nielicznymi wiadomościami, które dochodziły z frontu. Z czasem walki toczyły się na tyle blisko, że przetrzymywani w Bergen-Belsen je słyszeli. Więźniowie czerpali wiedzę również z mówionego czasopisma „Tramwaj”, wygłaszanego od czasu do czasu w baraku, zwykle wieczorem lub nocą. Konstruując wydanie, opierano się m.in. na informacjach pozyskanych z gazet niemieckich. Pisał o tym Józef Gitler-Barski, stryj Niny, który spędził w tym samym obozie niemal dwa lata. Oto kilka fragmentów jego zapisków:

Na treść gazetki składały się różne wiadomości bieżące i odpowiednio komentowane nowiny zaczerpnięte z gazet niemieckich. Konspiracyjne przynoszenie tych gazet z kantyny niemieckiej zorganizowaliśmy przez więźniów wyprowadzanych codziennie do sprzątania kantyny. Poza tym na treść „Tramwaju” składały się krótkie prelekcje i referaty wygłaszane przez niektórych z nas. Gazetka kontynuowana była przez cały czas naszego pobytu w Bergen-Belsen, mimo coraz dotkliwszego głodu, chorób i stałego zagrożenia życia [...].

31 I 1945. [...] Pogłoski o postępach radzieckiej ofensywy (Śląsk) [...]. 8 II 1945. [...] Wojska ofensywne podobno $40 \mathrm{~km}$ od Berlina. „Tramwaj” według danych z 22 I. Cała Gubernia Generalna w rękach wojsk radzieckich. W obozie duże podniecenie [...]. 15 III 1945.

„Tramwaj” - materiały z 1 III. [...] 1 IV 1945. [...]

Wojna zbliża się do punktu kulminacyjnego, ofensywa obejmuje coraz głębsze tereny Niemiec $[\ldots]^{13}$.

Równocześnie w Bergen-Belsen powstawała twórczość literacka, także dzięki temu, że wraz z przybyciem do obozu w 1943 roku więźniom pozwolono mieć własny bagaż, a co za tym idzie - papier czy ołówki. Prawdopodobnie na początku kwietnia 1945 roku, gdy wiadomości z frontu nadchodziło coraz więcej, Nina Gitler napisała wiersz Kajdany - jedyny w jej dorobku utwór wprost traktujący o oczekiwaniu na wyzwolenie:

Co nocną ciszę przerywa?

Czem pokój nocny przerwany?

Rwiemy, rwiemy kajdany

Za prawdę co wstała żywa

Za bliskich pogrzebanych

Przyjdzie szalona i mściwa

Nienawiść, gdy się przerwą kajdany.

Lecz nie chęć odwetu nas wzywa

Nie świeże krwawe rany 
Lecz zew wolności co przywarł

Do serc by rwały się kajdany

Kończą się krwawe żniwa

Świat cały krwią już zalany

Po całym świecie zew wzywa

Młodych by rwali kajdany

Nie starca głowa siwa

Nie starzec wiekiem sterany

Będzie rwał ogniwa

Przetnie niewoli kajdany

Pęknie ohyda fałszywa

Młody zapałem porwany

Będzie rwał kajdany

Kajdany będzie zrywał

I krzyczeć będziemy wiwat

I świat będzie odbudowany

Kiedy się przerwą ogniwa

Kiedy pękną kajdany ${ }^{14}$.

Gitler napisała w Bergen-Belsen wiele utworów poświęconych m.in. codziennemu życiu w obozie, jednak tylko ten odnosi się do nadchodzącego uwolnienia. Ostatecznie musiała na nie jeszcze poczekać około dwóch tygodni, do 22-23 kwietnia.

Motyw ostatnich dni w obozie i przeczucia, że niebawem więźniowie odzyskają wolność, pojawia się również w wierszach innych kobiet przebywających wówczas w Bergen-Belsen, np. Elżbiety Popowskiej. Utwory tej autorki, zamieszczone w książce Czy jest nadzieja? Wiersze polskie z Bergen-Belsen, odzwierciedlają właściwie etap po etapie atmosferę tamtych dni. W tekście pt. Czy to wyzwolenie? pojawia się przeczucie:

Coś ku nam idzie... czujemy te kroki,

Codziennie bliższe... jakiś wiew szeroki

Niesie półtrwożne, półradosne echa,

Błyskiem nadziei do nas się uśmiecha...

Na horyzoncie świecą groźne łuny,

Huczą bez przerwy armatnie pioruny,

Coś do nas idzie... Strzały i płomienie

Coraz są bliższe... Czy to wyzwolenie ${ }^{15}$

Relację zawartą w wierszu potwierdza Henryka Tajchert, która trafiła do Bergen-Belsen 2 marca 1945 roku: „Słyszało się odgłosy bombardowań"16. W innym utworze pt. Biate opaski, utrzymanym w podobnym, lecz dużo bardziej optymistycznym tonie, Popowska pisze już o tym, że kapitulacja staje się faktem:

Boże Miłosierny! Bodaj, że się stało...

Już nasi ciemiężcy na biało! na biało!

Opaski na rękawach! Koniec upragniony!

Widocznie zaniechali już dalszej obrony,

Kapitulują! Czy to nie złudzenie?!

Czy naprawdę koniec? Nasze wyzwolenie?!17

Wreszcie w wierszu zatytułowanym Wolni! Popowska opisuje moment odzyskania wolności:

Już przyszli! Już są u nas! Już za bramą drogą

Idą pierwsze oddziały! Idą! [...]

Wreszcie okrzyk: Anglicy!...

Niech żyją!... Niech żyją! ${ }^{18}$

O ostatnich dniach w obozie, skupiając się jednak nie na wkroczeniu Anglików, lecz tragicznej sytuacji więźniów, pisze również Gabriela Sudwoj:

Pasiaste widma o sczerniałej twarzy,

Potykając się, idą chwiejnym krokiem.

Patrzą w swą drogę obumarłym wzrokiem -

Widmowy pochód pasiastych grabarzy.

Za szmaty do rąk, do nóg przywiązane

Ciągną za sobą widma nieżyjące -

Trupy, mogiły dawno czekające -

Nagie szkielety w swą skórę odziane.

Rzuconym na wznak, ciągnionym za ręce,

Zwisa do tyłu głowa odchylona.

Zdaje się, człowiek ten aż dotąd kona,

Mimo bezsiły gwałcony w swej męce.

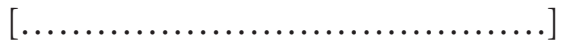

Czemu to jednak nie ja na tym stosie

Patrzę obliczem zastygłym w udręce,

Czemu nie moje sterczą z stosu ręce,

Czemu miast komuś - mnie ta łaska w losie? ${ }^{19}$

W wypadku przywołanych wierszy dużo ważniejszy niż wartość artystyczna wydaje się przekaz - będący niezaprzeczalnym świadectwem losu, którego doświadczyły autorki. 
Jak zaznaczał już w 1946 roku Michał Borwicz: „[...] żadnego z nich [utworów literackich - W. G.] nie należy oceniać w oderwaniu od warunków, w jakich powstał" ${ }^{20}$. Wiersze obozowe - podobnie jak „literatura getta”, by odnieść się do określenia Bernarda Marka - zostały napisane przez „ludzi skazanych na niechybną zagładę, ludzi żyjących stale w cieniu śmierci"21. Napisane, można dodać, w sytuacji skrajnej, ekstremalnej, a zatem oddające ówczesne nastroje, emocje, przewidywania. To również w pewnej mierze tłumaczy, dlaczego tak wiele osób - w różnym wieku, niezajmujących się wcześniej pisaniem - postanowiło utrwalić swoje przeżycia w postaci utworów literackich. Niektóre wiersze lub ich fragmenty wyróżnia stosunkowo wysoka wartość artystyczna.

\section{Obóz w kwietniu 1945 roku}

W Bergen-Belsen 15 kwietnia 1945 roku przebywało ok. 55000 więźniów; w ciągu dwunastu następnych tygodni zmarło ok. $13000 \mathrm{z}$ nich ${ }^{22}$. Wojskowi, fotografowie, reporterzy, którzy weszli do obozu po wyzwoleniu, byli wstrząśnięci. Wykonano wiele zdjęć, spisano relacje $e^{23}$ - jedną z nich, zawierającą opis zastanej sytuacji, zatytułowano Belsen Horror Camp ${ }^{24}$. Wśród przybyłych na miejsce był m.in. Patrick Gordon Walker, który zanotował, że na całym terenie obozu leżały zwłoki, na domiar złego więźniowie wciąż umierali z wygłodzenia albo trapieni chorobami. W tym ostatnim wypadku, gdyby działania służb były sprawniejsze - zdaniem Walkera - można było uratować więcej osób ${ }^{25}$. Jego obserwacje potwierdził Paul Weindling, analizując sytuację w Bergen-Belsen tuż po wkroczeniu Anglików ${ }^{26}$. Ponadto część więźniów otrzymała zbyt duże posiłki. Ten wątek pojawia się m.in. we wspomnieniach Henryki Tajchert:

A były oprócz tych konserw tak jak obecne krakersy, keksy. Kto umiał sobie tylko sobie [sic!] dawkować, co godzinę pół keksa potem co pół godziny, ten przeżył. Ale znam cały szereg przypadków bliskich mi osób, które nie były w stanie zapanować nad głodem i od razu wykończyły się w silnych boleściach ${ }^{27}$.

W ciągu kilku następnych tygodni pochowano - kierując do tej pracy niemiecki personel dawnego obozu ok. 10000 ciał zmarłych osób, a także spalono baraki, w których wcześniej przebywali zarażeni tyfusem. Zorganizowano szpital tymczasowy. Byłych więźniów przeniesiono do baraków SS, a także zapewniono opiekę m.in. ze strony niemieckich pielęgniarek - przeciwko tej decyzji jednak stanowczo protestowano ${ }^{28}$. Pojawiły się pierwsze próby repatriacji do krajów pochodzenia, ponadto niektóre państwa zaproponowały uwolnionym - pod pewnymi warunkami, o czym piszę więcej w końcowej części artykułu - udział w programach pomocowych lub możliwość emigracji. W dawnym obozie otwarto również szkołę, w której uczono pisania dzieci z Polski, Czechosłowacji i Węgier - naukę prowadzono w języku niemieckim, ponieważ tylko ten był dla wszystkich uczniów zrozumiały ${ }^{29}$. W następnych miesiącach utworzono liceum, przedszkole i jesziwę ${ }^{30}$. Wcześniej, przed wyzwoleniem, lekcje potajemnie prowadzono w barakach ${ }^{31}$.

Reporterzy odnotowali, że dawni więźniowie - mimo trudnej sytuacji - po raz pierwszy od lat obchodzili szabas. W sobotni poranek, 21 kwietnia, odbył się z kolei spontaniczny koncert ${ }^{32}$. W tym czasie swoją relację spisała Rivka Levi. Podobnie jak Gabriela Sudwoj w przywołanym wcześniej utworze, również ta autorka nie pominęła drastycznych szczegółów; podjęła także refleksję na temat tego, z jakimi długotrwałymi konsekwencjami będą musieli zmierzyć się więźniowie Bergen-Belsen. Relację, ze względu na jej artystyczną i emocjonalną wartość, postanowiłem przywołać w całości:

Pierwszy wieczór sobotni w Bergen-Belsen wyzwolony. Dzień się chylił ku końcowi. Odblaski zachodzącego słońca rozjaśniały połacie lagru Bergen-Belsen. W jego świetle wyraźnie rysowały się ślady pobojowiska, pobojowisko bez krwi... Walały się po ziemi łachmany, kupy strzępków zawszonych po żywych i umarłych. Gdzieniegdzie spod nich wyglądała twarz trupa sina, niema, zastygła w bólu niemocy. Jeszcze w powietrzu unosiła się woń zgnilizny i rozkładu, jeszcze wokoło ślady bestii, już teraz zwalonej, pokonanej... Ślady te starali się Anglicy, nasi wybawcy, uprzątnąć jak najszybciej. Zaprzęgnięci teraz do tej pracy Niemcy pracowali już od szeregu dni, ale dzieło zagłady wydało tak obfite plony, że nie sposób je było zatrzeć w tak krótkim czasie. Stale przybywały trupy, jeszcze więź[niowie?] umierali, choć byliśmy już wyzwoleni.

Wyglądam przez okno baraku i myślę: ubiegnie jeszcze kilka dni, a może tygodni i nie będzie znaku ni śladu po „Bergen-Belsen”, ślady zostaną w nas samych...

Pierwsze dni oszołomienia uzyskaną wolnością minęły. Zbyt znużone i wycieńczone, a co najbardziej - świadome prawdy bolesnej, nie potrafiłyśmy się cieszyć więcej. Grasowała dyzenteria i tyfus. Z naszego baraku, do którego przeniosłyśmy się zaraz po oswobodzeniu 39 towarzyszek wspólnej niedoli jeszcze z lagru w Bremen, wyjęto 
już dwie chore, a już [-] zwalona wysoką gorączką na pryczy [-]. Wyglądam oknem i myślę: ależ największym pragnieniem było przeżyć. Przeżyłam i co dalej?

Nagle otwarły się drzwi naszej izby i stoi w nich oficer angielski i pyta: znajdują się tu juden? Był to rabin w wojsku angielskim i przyniósł nam świece, by zapalić, bo zaraz zapada sobota. Zaraz szabas, powiedział i szybko się oddalit. Zapalono świece szabasowe. W cichym skupieniu stałyśmy dookoła świec.

Biedne świeczki szabasowe, jako i my biedne. Na jakiejś skrzynce złamanej, co służyła jako stolik bez obrusa, w pobliżu nagiej pryczy i brudnych ścian, płomyki strzelały w górę. Ile czasu upłynęło od ostatnich świec szabasowych? Może wieki całe. Żarzące, suche oczy spoglądały na świece. Szabas, znowu szabas na świecie?

Ale my bezdomne, bezdomne sieroty. Zapadł zmrok. Świece dogasały. Każda znalazła swe miejsce na pryczy. Ciemność zupełna w baraku i cisza, którą od czasu do czasu przerywa westchnienie albo powtarzaną przez chorą słowo: szabas, szabas ${ }^{33}$.

Istnieje również druga wersja przytoczonej relacji sporządzona 21 kwietnia 1945 roku. Oba teksty różnią się kilkoma szczegółami, m.in. zakończeniem: „Ciemność zupełna w baraku. Każda znalazła swe miejsce na pryczy. Cisza, którą od czasu do czasu przerywa westchnienie o [-] chorej w tę pierwszą noc sobotnią w Bergen-Belsen wyzwolony"34.

Jak pisze Ellen Ben-Sefer, w kwietniu 1945 roku do Bergen-Belsen wysłano siostry m.in. z Queen Alexandra’s Imperial Military Nursing Service czy brytyjskiego Czerwonego Krzyża. Dodatkowo - o czym wspomniano wcześniej zaangażowano ok. 200 niemieckich pielęgniarek; jednak praca tych ostatnich nie została jednoznacznie pozytywnie oceniona. W kwietniu 1945 roku personel medyczny borykał się z wieloma problemami, począwszy od bariery językowej, przez ryzyko wybuchu histerii (gdy więźniowie usłyszeli działające prysznice), po zmagania w walce o zdrowie ocalonych, którzy byli skrajnie wycieńczeni i schorowani. Pielęgniarki pomagały w powrocie do zdrowia, ale zapewniały także wsparcie psychiczne - część nawiązanych wówczas przyjaźni miało przetrwać jeszcze wiele lat, o czym świadczą np. listy z podziękowaniami przesyłane siostrom po wojnie. $Z$ drugiej strony - będąc świadkami tragicznych warunków w obozie pielęgniarki same zmagały się później z traumą, nie mogąc zapomnieć o tym, co zobaczyły w Bergen-Belsen ${ }^{35}$.

W tym samym czasie do obozu zostało skierowanych 95 studentów medycyny z sześciu londyńskich szkół - spędzili tam prawie miesiąc, pomagając w leczeniu byłych więźniów, jak również rozwiązując pilne kwestie techniczne związane np. z dezynfekcją baraków. Jeden z nich, Michael Hargrave, prowadził dziennik, w którym opisał ówczesne zmagania. Dokument obejmuje 87 stron, pierwszy wpis sporządzono 28 kwietnia - tego dnia Hargrave dowiedział się, że zostanie wysłany do Bergen-Belsen (a nie do Holandii, jak pierwotnie przypuszczał), ostatni natomiast - 28 maja. Notatki opatrzono fotografiami, wycinkami z prasy ${ }^{36}$ oraz rysunkami, np. planu obozu oraz baraku, w którym wcześniej przebywało 260 osób, ogrodzenia i wieżyczek strażników, mapy, na której student oznaczył podróż samolotem z Cirencester do Celle, niedaleko obozu. Hargrave stał się specjalistą w dziedzinie chorób, które trapiły więźniów: biegunki, tyfusu czy niedożywienia ${ }^{37}$. Pracował z dużym oddaniem, a jego starania wykraczały czasem poza pomoc medyczną - by przełamać barierę językową, uczył jedną z kobiet, Zofię Wiśniowską, języka angielskiego. Ponadto przytacza w dzienniku rozmowę z jednym z oficerów, Glyn-Hughesem ${ }^{38}$, który opowiadał o okolicznościach wkroczenia do Bergen-Belsen 15 kwietnia i zastanej tam sytuacji, m.in. o odnalezieniu na jego terenie byłego komendanta Josefa Kramera, który dwa dni przed wyzwoleniem - zgodnie z rozkazami przesłanymi z Berlina - zniszczył obozową dokumentację ${ }^{39}$. Wszystkie dawne więzienne bloki spalono 21 maja 1945 roku. Pozostawiono jednak budynki SS, do których przeniesiono ocalonych. W lipcu 1945 roku w Bergen-Belsen powstał obóz dla dipisów (ang. displaced persons).

\section{Życie po Bergen-Belsen}

Wielu więźniów, jak choćby bohaterowie książki $C z y$ jest nadzieja? Wiersze polskie z Bergen-Belsen: Jerzy Chorzewski, Jadwiga Jasielska, Elżbieta Ostrowska-Gross, Hanna P., Elżbieta Popowska, Wanda Stanicka-Wielgosz, Wanda Świerzewska, ostatecznie wróciło do Polski; Jerzy Orłowski (Uri Orlev) wyjechał do Izraela, Gabriela Sudwoj do Kanady lub Stanów Zjednoczonych.

Jednak losy wielu innych długo pozostawały niepewne. Jeszcze na początku 1946 roku w Bergen-Belsen przebywało ok. 9000 Żydów, a w całej brytyjskiej strefie okupacyjnej 16 000. Wiele osób zatrzymało się w miastach zlokalizowanych w pobliżu dawnych obozów, czekając na rozwój wydarzeń ${ }^{40}$. Nie wszyscy chcieli wracać do swoich krajów wyzwoleni myśleli bowiem o emigracji do Palestyny, Stanów Zjednoczonych, Wielkiej Brytanii, inni z kolei woleli pozostać w Niemczech. 
Pomoc, już w 1946 roku, zaoferowała Szwecja - podupadli na zdrowiu byli więźniowie mogli odbyć tam rekonwalescencję; część z nich została na dłużej i podjęła pracę. Podobne wsparcie chorym na gruźlicę zapewniły Włochy i Szwajcaria. Istniała możliwość otrzymania pracy w innych krajach, choć pod pewnymi warunkami. W marcu 1947 roku dwudziestu ośmiu wykwalifikowanych pracowników trafiło do Norwegii. W tym samym roku Wielka Brytania rozpoczęła program „Westward Ho” adresowany do byłych więźniów celem było znalezienie 100000 pracowników fizycznych. Kraje, takie jak Norwegia i Kanada, pisze Paul Weindling, m.in. ze względu na niedobór siły roboczej, poszukiwały osób, które mogły być „ekonomicznie produktywne”; jednak warunkiem przystąpienia do niektórych programów było przejście badań lekarskich ${ }^{41}$ - celem kontroli było wyeliminowanie tych spośród byłych więźniów, którzy byli „słabi, chorzy i straumatyzowani” ${ }^{42}$. Doszło zatem do następnej selekcji, która dla wielu dawnych więźniów okazała się nie do przejścia. Po wojnie część osób, w tym dzieci, które przeżyły Bergen-Belsen, trafiła do niemieckich szpitali psychiatrycznych m.in. z powodu schizofrenii. Jeszcze w 1955 roku w Europie Zachodniej nadal pozostawało ok. 253000 dipisów - wśród których odnotowywano skłonność do depresji i samobójstw ${ }^{43}$. Ostatnie osoby opuściły Bergen-Belsen, będący już wówczas obozem DPs, dopiero w sierpniu 1951 roku.

Key Words: Holocaust, Bergen-Belsen, liberation, literary account, witness, 1945

Abstract: On April 15, 1945, Bergen-Belsen concentration camp was liberated by the British. Over the next few weeks, attempts were made to rescue the prisoners, but in many cases they failed. Reporters, photographers and medical staff as well as former prisoners described the first days in the former camp. From reports, notes, and other documents written on an ongoing basis, as well as memoirs written in the years after the war, emerges the true, tragic condition of the German camp in April 1945.

This article compiles the accounts of witnesses: both survivors and the people who contributed to their release, in an attempt to show how the liberation of the camp, as well as the situation in the camp in the following months, looked. The text cites archival materials found during searches conducted in 2019 and 2020 at Yad Vashem, The World Holocaust Remembrance Center in Jerusalem and the Jewish Historical Institute in Warsaw.
O nieznanych utworach literackich piszę m.in. w artykułach: „O honor” (1950) Jakuba Herziga, nieznany dramat na temat powstania w getcie warszawskim („Archiwum Emigracji” 2021, w druku) oraz Inedita z Yad Vashem i Zydowskiego Instytutu Historycznego. Twór czość poetycka Niny Gitter (w trakcie recenzji). Następne publikacje na ten temat - w przygotowaniu.

T. Nizielski, Bergen-Belsen 1943-1945, Warszawa 1971, s. 3-4.

Ibidem, s. 4-5.

"A. Haska, „Jestem Żydem, chce wejść”. Hotel Polski w Warszawie, 1943, Warszawa 2006, s. 66 i in.; B. Horstmann, Bergen-Belsen Main Camp, w: The United States Holocaust Memorial Museum Encyclopedia of Camps and Ghettos, 1933-1945, Volume I,

ed. G. P. Megargee, Bloomington 2009, s. 278.

${ }^{5}$ T. Nizielski, op. cit., s. 6-15 i 22. Ponadto: H. Lavsky, New Beginnings: Holocaust Survivors in Bergen-Belsen and the British Zone in Germany 1945-1950, Detroit 2002, s. 37-41.

${ }^{6}$ Istniejący w latach 1941-1945 kompleks niemieckich obozów koncentracyjnych.

${ }^{7}$ B. Horstmann, op. cit., s. 280.

Yad Vashem, sygn. 0.76, t. 305

"J. A. Polak, The Lost Transport, "Commentary” 1995, No. 2 (30), s. 24. Ponadto: The Lost Train: Bergen-Belsen to Tröbitz, preface P. Landé: http://www.musiques-regenerees.fr/ GhettosCamps/Camps/TheLostTrain_Bergen-BelsenToTroebitz.html (dostęp: 29.10.2020), a także: H. Lavsky, op. cit., s. 39.

"Belsen and The Listeners. What Wireless Listeners Learned, „History Today” 2006 No. 8 (56), s. 35; S. Bardgett, Foreword, w: D. B. Hargrave, Bergen-Belsen 1945: A Medical Student's Journal, London 2014, s. XVII.

Yad Vashem, sygn. 0.76, t. 201, k. 155.

${ }^{12}$ Ibidem, k. 156-157.

${ }^{3}$ J. Gitler-Barski, Przeżycia i wspomnienia z lat okupacji, Wrocław 1986, s. 78 i 102-103.

${ }^{4}$ Fragment tego wiersza, obok kilku innych, zamieściłem we wspomnianym wcześniej artykule pt. Inedita z Yad Vashem i Żydowskiego Instytutu Historycznego. Twórczość poetycka Niny Gitler. Tutaj natomiast postanowiłem podać jego pełną wersję - por. Yad Vashem, sygn. 0.76, t. 201, k. 28

${ }^{15}$ E. Popowska, Czy to wyzwolenie?, w: Czy jest nadzieja? Wiersze polskie z Bergen-Belsen, zebr. i oprac. K. Liedke, Celle-Warszawa 2007, s. 204.

${ }^{16}$ P. Czyż, Wspomnienia Henryki Tajchert z Włodawy - więźniarki Zamku Lubelskiego, Ravensbrück i Bergen-Belsen, „Radzyński Rocznik Humanistyczny” 2013, t. 11, s. 81.

${ }^{17}$ E. Popowska, Białe opaski, w: Czy jest nadzieja?, s. 206.

${ }^{18}$ Eadem, Wolni!, w: ibidem.

${ }^{19}$ G. Sudwoj, Ostatni tydzień w Bergen-Belsen, w: ibidem, s. 228-230.

${ }^{20}$ M. Borwicz, Literatura w obozie, Kraków 1946, s. 68.

${ }^{21}$ Określenie Bernarda Marka, O twórczości literackiej w gettach. Rysy ogólne, „Biuletyn Żydowskiego Instytutu Historycznego" 1952, nr 1, s. 191.

${ }^{22}$ B. Horstmann, op. cit., s. 280.

${ }^{23}$ Wiele z nich jest dostępnych w kolekcji Imperial War Museums; zob. np. https://www. iwm.org.uk/collections/search?query=bergen-belsen\&pageSize=90\&media-records=all-recor ds\&style=list (dostęp: 7.04.2021).

${ }^{24}$ The Liberation of Bergen-Belsen Concentration Camp, April 1945: https://www.iwm org.uk/collections/item/object/205229733 (dostęp: 7.04.2021).

${ }^{25}$ Belsen and The Listeners. What Wireless Listeners Learned, s. 30 i 33.

${ }^{26}$ P. Weindling, "Belsenitis": Liberating Belsen, Its Hospitals, UNRRA, and Selection for Re-emigration, 1945-1948, „Science in Context” 2006, No. 19 (3), s. 416

${ }^{27}$ P. Czyż, op. cit., s. 81.

${ }^{28}$ P. Weindling, op. cit., s. 408

${ }^{29}$ W kolekcji Imperial War Museums jest dostępne zdjęcie wykonane podczas jednej z lekcji; The Liberation of Bergen-Belsen Concentration Camp, June 1945: https://www.iwm org.uk/collections/item/object/205214666 (dostęp: 7.04.2021).

${ }^{30}$ Bergen-Belsen Displaced Persons Camp: https://encyclopedia.ushmm.org/content/ en/article/bergen-belsen-displaced-persons-camp (dostęp: 11.04.2021).

${ }^{31}$ Wspomina o nich m.in. Celina Barska, która trafiła do Bergen-Belsen w lipcu 1943 roku. Miesiąc później zaczęła prowadzić lekcje dla dzieci w wieku od 6 do 11 lat: „Pisało się jednym kawałkiem ołówka na wyciągniętej z pryczy desce [...]. Ja pisałam dużymi literami i cyframi na desce, po mnie kolejno pisały dzieci. W ten sposób odbywało się nauczanie czytania, pisania i początków rachunków w zakresie dwóch działań: dodawania i odejmowania [...]. Zakończenie zajęć odbyło się w grudniu 1944 r., kiedy już ani ja, ani dzieci nie mieliśmy z głodu sił do nauki”; C. Barska, Szkoła na pryczy, „Biuletyn Żydowskiego Instytutu Historycznego" 1989, nr 3 (151), s. 95-96.

${ }^{32}$ Belsen and The Listeners. What Wireless Listeners Leamed, s. 33.

${ }^{33}$ Yad Vashem, sygn. 0.76, t. 83, k. 14. 
${ }^{34}$ Yad Vashem, sygn. 0.76, t. 309, k. 13-14.

${ }^{35}$ E. Ben-Sefer, Surviving Survival: Nursing Care at Bergen-Belsen 1945, „Australian Journal of Advanced Nursing" 2009, No. 3, s. 105-109.

${ }^{36}$ Tytuły artykułów: 95 Medical Students to Help Belsen, Medical Students Off to Belsen, Are Flying to Belsen, Report to Britain on Belsen.

${ }^{37}$ S. Bardgett, Foreword, w: D. B. Hargrave, Bergen-Belsen 1945: A Medical Student's Journal, London 2014, s. viii.

${ }^{38}$ Hugh Llewellyn Glyn Hughes (1892-1973) - brytyjski wojskowy, uczestnik pierwszej i drugiej wojny światowej. Jako pierwszy aliancki oficer medyczny 15 kwietnia 1945 roku wszedł do obozu Bergen-Belsen.

${ }^{39}$ M. J. Hargrave, Belsen-Bergen. Diary, w: D. B. Hargrave, op. cit., s. 34-36 i 43.

${ }^{40}$ H. Lavsky, op. cit., s. 61.

${ }^{41}$ Badania przechodziły również osoby udające się na rekonwalescencję do Szwecij: „I właśnie po odwszawieniach, po wszystkich dezynsekcjach w różnych komorach, w ga zach, po badaniach bardzo ścisłych lekarskich z uznaniem wszystkich chorób, ale chodziło, aby nie przenosić dużo zarazków do Szwecji”; P. Czyż, op. cit., s. 82.

42 "Belsenitis": Liberating Belsen, Its Hospitals, UNRRA, and Selection for Re-Emigration, 1945-1948, s. 411-412.

${ }^{43}$ Ibidem, s. 409 i 417

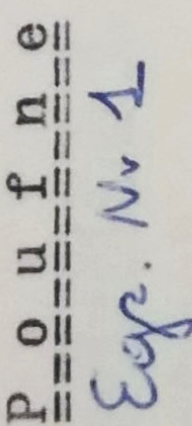

